\title{
Avoiding the greenwashing trap: between CSR communication and stakeholder engagement
}

\section{Agostino Vollero*, Maria Palazzo and Alfonso Siano}

Department of Political,

Social and Communication Sciences,

University of Salerno,

Via Giovanni Paolo II, 132,

84084 Fisciano (SA), Italy

Email: avollero@unisa.it

Email: mpalazzo@unisa.it

Email: sianoalf@unisa.it

${ }^{*}$ Corresponding author

\section{Wim J.L. Elving}

ASCoR, Amsterdam School of Communication Research,

IE University, Madrid,

University of Amsterdam,

Nieuwe Achtergracht 166,

1018 WV Amsterdam, The Netherlands

Email: W.J.L.Elving@uva.nl

\begin{abstract}
The paper analyses key elements of communication that may lead to accusations that a company is engaging in practices of greenwashing failing to create stakeholder engagement. According to sensemaking and sensegiving approaches, the theoretical foundations that underpin the concepts of corporate social responsibility (CSR) communication and greenwashing practices are explored and a comparison between two energy companies in the Italian and Dutch context is set up for exploratory purpose. The integration of a company's strategic CSR approach and its communication practices may help to enhance effective stakeholder engagement, prevent accusations of greenwashing and avert the negative associated consequences (e.g., scepticism among stakeholders). The research provides a theoretical contribution to CSR communication by identifying several pitfalls that can lead to the appearance of greenwashing and provides caveats for the further development of both theory and managerial practices.
\end{abstract}

Keywords: CSR; greenwashing; corporate communication; stakeholder engagement; energy industry; communication ideal; identification of CSR structure; strategic communication task; corporate communication style.

Reference to this paper should be made as follows: Vollero, A., Palazzo, M. Siano, A. and Elving, W.J.L. (2016) 'Avoiding the greenwashing trap: between CSR communication and stakeholder engagement', Int. J. Innovation and Sustainable Development, Vol. 10, No. 2, pp.120-140. 
Biographical notes: Agostino Vollero, $\mathrm{PhD}$, is Researcher and Lecturer at the Department of Political, Social and Communication Sciences, University of Salerno (Italy). His primary research interests are in the areas of corporate communication, social responsibility, digital marketing and corporate reputation. He has published two books and various papers in Italian and international journals, including Journal of Brand Management and Journal of Marketing Communications.

Maria Palazzo is a Research Fellow at the University of Salerno (Italy). Previously, she was Lecturer at the University of Bedfordshire Business School (UK). Moreover, she has a PhD in 'Marketing and Communication'. She discussed a $\mathrm{PhD}$ thesis titled 'Exploring Corporate Communication: An Application and Extension. A Survey of Large Italian Companies'. Her research focuses on corporate communication, marketing and marketing communication, stakeholder relationship and CSR.

Alfonso Siano is a Professor and Chair of Corporate Communications and of Marketing Communications at the University of Salerno (Italy). He has previously been Researcher and Lecturer in Management at the University of Rome 'La Sapienza'. He teaches and carries out research in corporate communications, corporate sustainability, marketing communications, arts and heritage marketing, and digital marketing. He has published eight books and articles in a wide range of international academic journals, including the Journal of Marketing Communications, Corporate Communications: An International Journal, Journal of Brand Management, Journal of Communication Management, International Studies of Management and Organization.

Wim J.L. Elving is an Assistant Professor of Corporate Communications at the University of Amsterdam. He is Editor in Chief of Corporate Communications: an International Journal. He has been teaching at several Universities, besides Twente (PhD) and Amsterdam (current) in Denmark (Aarhus), Italy (Salerno), Slovenia (Ljubljana), Finland (Oulu) and Madrid (Spain). His research focuses on communicating organisational change, corporate communications, corporate branding and CSR communication.

Although the views and ideas expressed in this paper are those of Agostino Vollero, Maria Palazzo, Alfonso Siano and Wim Elving, Sections 2 and 3 are attributed to Agostino Vollero, Section 4 to Maria Palazzo, Section 5 to Alfonso Siano and Section 1 to Wim Elving.

\section{Introduction}

In the last two decades, CSR is becoming a standard practice and companies are usually requested to act and present themselves as 'sustainable' entities by specific groups of stakeholders (consumers, local communities, NGOs, media, etc.) (Aras and Crowther, 2008; Ziemann, 2011). Besides, the willingness of consumers to buy environmentally friendly products has been increasing over time, regardless economic recession or geographic region (Eurobarometer, 2009; Harris Interactive, 2012; National Geographic/GlobeScan, 2012).

Accordingly, firms have tried to enhance their commitment to sustainability and progressively increased the use of 'social responsibility' component in their corporate 
and marketing communications (Jahdi and Acikdilli, 2009). Many companies thus find it profitable to invest in CSR, and some companies "may be tempted to communicate over a non-existent or overestimated effort in CSR" (Bazillier and Vauday, 2010, p.2).

This manipulation of corporate image is often referred to as 'greenwashing, i.e., the tendency of some corporations to manage their communications with stakeholders creatively, "so as to hide deviance, deflect attributions of fault, obscure the nature of the problem [...] and, finally, seek to appear in a leadership position" (Laufer, 2003, p.255) in one or more dimensions of CSR. Companies that apply the practice of greenwashing, therefore, use CSR communications to try to deflect attention from their unethical conduct to attract eco-conscious consumers, prevent protest and appear to be in line with government regulations. Broadly, greenwashing makes a selective disclosure of only positive information about a company's performance to deflect attention from its environmental and social shortcomings. This behaviour intends to build reputational capital and to influence customers' price fairness evaluations while the organisation continues to conduct business in a way that would be viewed as unacceptable if people were aware of it (Lyon and Maxwell, 2011).

Various studies, indeed, have also highlighted the sceptical response of consumers to the marketing messages of organisations who communicate extensively on their CSR programs (Brown and Dacin, 1997; Sen and Bhattacharya, 2001; Signitzer and Prexl, 2008; Ilia et al., 2013). Companies generally instigate a two-way communication strategy to prevent CSR communications from appearing to be merely cosmetic, but "the skyrocketing incidence" of deliberate greenwashing practices has still led to increasingly sceptical responses from consumers (Schlegelmilch and Pollach, 2005; Delmas and Burbano, 2011). A survey in the USA revealed that scepticism is increasing as nearly one-third of consumers do not "trust the environmental claim on the product", without making any distinction between 'genuine' and deceitful messages (Cone Communications, 2012). But at the same time, over $70 \%$ of consumers declare that "want companies to provide more information about the environmental impact of products". This can even lead to a 'prisoner's dilemma' whereby responsible firms may even benefit from stopping their responsible practices continuing only to communicate (Elving and van Vuuren, 2011; Parguel et al., 2011; Bowen and Aragon-Correa, 2014). Thus, the potential benefits of CSR communication may be questionable, even for companies behaving in a genuinely sustainable way, because they could also suffer from the same greenwashing risk.

Despite being an object of study across different disciplines since the 1990s, few studies have outlined the conceptual dimensions of greenwashing systematically (Athanasiou, 1996; Laufer, 2003; Bazillier and Vauday, 2010; Delmas and Burbano, 2011; Lyon and Maxwell, 2011; Marquis and Toffel, 2012). And even fewer outlined the contributions that investigated the shortcomings in the management of communication that lead to accusations of the attempted greenwashing of company's image (Signitzer and Prexl, 2008; Marquis and Toffel, 2012). In this direction, a key challenge for managers would be mitigating stakeholder scepticism and "communicate CSR achievements without being accused of greenwashing" (Ilia et al., 2013, p.16).

Considering the urgency of these gaps, this paper intends to provide two main incremental contributions to the extant literature: 
- To identify theoretically several pitfalls in CSR communication that can lead stakeholders, especially consumers, to accuse a company is engaging in greenwashing.

- To present a method of analysis of CSR based on communication dimensions and stakeholder engagement as key areas of investigation. In so doing, according to the sensemaking and sensegiving approach (Weick, 1995; Gioia et al., 1994), the paper proposes an explorative analysis on how two firms are aware of greenwashing risk in their CSR communication, addressed in particular to consumers. In both cases, they are considered primary stakeholders of the surveyed companies, as emerged from the interviews with key managers and from official documents available on their corporate websites (e.g., mission statement, materiality matrix).

Managerial implications are then discussed, suggesting different business recommendations in communication approach of companies in the perspective of minimising the risk of appearing to participate in greenwashing practices, thanks to a proper approach to stakeholder engagement. These contributions are conceptualised showing a degree of continuity with respect to recent literature on CSR communication and stakeholder engagement.

\section{Conceptual background: exploring pitfalls in CSR communication}

According to Ziek (2009), the literature that currently focuses on CSR communication is varied and encompasses different approaches that determine a lack of in-depth analysis of the different ways of communicating CSR, thereby resulting in a poor understanding of the phenomenon by scholars and professionals.

Although previous studies have laid much of the foundation for an understanding of the communication drivers that lead to the perception that a company is engaging in greenwashing, an analysis of the basic dimensions that constitute CSR communication is still lacking. In this section, we describe the main CSR communication dimensions (Morsing and Schultz, 2006), according to sensemaking and sensegiving approaches (Weick, 1995; Gioia et al., 1994), illustrating associated root causes and pitfalls which contribute to generate the greenwashing effect. Thus, our point of view is focused on how managers try "to make and give sense of things" and consequently are able to integrate the sensemaking of stakeholders and to enact strategically a productive relationship (Gioia et al., 1994), i.e., to create stakeholder engagement. Basically, stakeholder engagement can help organisations for the fact that they could participate in a regulatory approvals process, improve stakeholder relationships proactively, or solve CSR obstacles and possible crises (Miles et al., 2006; James and Philips, 2010). Including stakeholders from the start of the process and involve them in developments in which they would otherwise have little influence or no information at all could be a tool to reduce risks of greenwashing. Bebbington et al. (2007) suggested that, for example, in the case of the creation of 'socially responsible' investor community, even if it may appear to be 'greenwash', indeed, it could open up possibilities for individuals or groups (i.e., communities of interest) to increase their power of voice.

In this perspective, stakeholder engagement is not related to the 'quantity' of contacts between the parts (i.e., "the more an organisation engages with its stakeholders, the more it is responsible" - Greenwood, 2007, p.315), but it concerns the complexity of the 
relationship between company and its stakeholders to put in action CSR initiatives. Following a critical dialogue approach, in fact, the tension towards stakeholder engagement could be expressed in terms of 'multiple narratives' and different forms of sustainability accounts, which are thought to hold promise for substantive emancipatory changes (Thomson and Bebbington, 2005; Bebbington et al., 2007).

\subsection{Communication ideal}

The first dimension of CSR communication that should be considered is the idea of the CSR that a company would like to pursue. This dimension deals with the value that is assigned to corporate responsibility in general and to CSR communication in particular. A (strategic) communication ideal could assume different forms ranging from a one-way communication, in which the company views communication only as a means of conveying information to the public, to a fully two-way communication process (symmetrical or asymmetrical) that emphasises a more dialogical view of communication (Grunig and Hunt, 1984).

Symmetrical two-way communication processes depend on a mutual understanding between the parties and imply that, before communicating their CSR messages, companies seek advice from, have discussions and engage with stakeholders. Through the lens of the theory of sensemaking (Weick, 1995; Morsing and Schultz, 2006), a oneway approach is a 'simple' sensegiving process, whereas an authentic two-way communication builds iteratively on both processes of sensemaking and sensegiving. The lack of useful feedback caused by very few points of contact or collaboration between companies and their stakeholders reduces the possibility of fine-tuning CSR communication initiatives (Peloza and Falkenberg, 2009).

Public perception of the gap between a company's socially irresponsible behaviour and its CSR communication may have a detrimental effect on the company and its products (Brown and Dacin, 1997; Swaen and Vanhamme, 2003; Signitzer and Prexl, 2008). Thus, pitfalls in CSR communication can be caused by low levels of correspondence between CSR communication programs and stakeholder expectations (Brown and Dacin, 1997; Sen and Bhattacharya, 2001; Swaen and Vanhamme, 2003) and/or corporate identity (Balmer et al., 2007; van de Ven, 2008).

Companies that do not take this potential hazards into consideration can be perceived to be involved in short-term problem solving (Waddock, 2001; Freeman and McVea, 2001; Pomering and Johnson, 2009) and in promoting a communication strategy that claims to be two-way but in fact does not give any worth to the feedback and engagement of different stakeholders (Crane and Livesey, 2003; Schultz and Wehmeier, 2010). This can result in a gap between CSR as perceived by common social groups and non-governmental organisations and the CSR principles endorsed at the corporate level (Dobers and Springett, 2010).

\subsection{Identification of CSR structure}

The second dimension of CSR communication concerns the identification of the CSR structure, in other words, the definition of the CSR decision-making processes and information flows. From a communicative standpoint, coordination is the most important feature of this dimension, by virtue of the fact that it ensures the integration and consistency of messages and a high level of correspondence between the company's 
communication and its behaviour (Siano et al., 2013; Vollero, 2013). This harmonisation must also be achieved inside the company. In fact, CSR communication strategies determined by top management and not fully communicated inside the company or to the public (Basu and Palazzo, 2008; Ligeti and Oravecz, 2009) result in organisations being unable to engage in dialogue with multiple stakeholders (Weaver et al., 1999; Signitzer and Prexl, 2008; Schmeltz, 2014). In general, employees are not usually involved in CSR decision-making processes and flows, and they frequently receive one-way messages about CSR decisions made by CEOs and top managers (Ligeti and Oravecz, 2009). This means that companies fail to utilise the full potential of employees as active CSR communicators (Cramer et al., 2004), who are often seen as credible sources of information by other stakeholders. This lack of internal coordination may result in ineffective intra-firm communication, thereby causing the sustainability aspects of a product/service to be overstated by PR and marketing departments (Delmas and Burbano, 2011).

\subsection{Strategic communication task}

The strategic objectives of a CSR communication strategy clearly have an influence on perceptions of greenwashing. As stated previously, greenwashing activities have led to sceptical reactions to CSR-related initiatives, especially when profit is thought to be the prime motivation for a company's engagement in CSR (Becker-Olsen et al., 2006; van de Ven, 2008; Signitzer and Prexl, 2008).

According to Dawkins (2005), there are other key lessons for companies to learn in relation to CSR communication. One such lesson refers to the importance of developing "[...] a clear communications strategy, taking into account which aspects of the responsibility program best fit with corporate reputation and with stakeholders' concerns" (Dawkins, 2005, p.119). Moreover, following a clear CSR communications strategy can allow organisations to reach new market opportunities, reduce risk and better prioritise resources and actions (Perrini and Tencati, 2008; Veleva, 2010). In some cases, a lack of a clear communication strategy may be linked to an attempt of dissimulating the environmental problems with which the company is linked (Brown and Dacin, 1997; Laufer, 2003), and of deflecting any fault that may be attributed to the company. CSR communication of poorly performing companies is perceived as intricate 'language': syntactical difficulties in the corporate annual CSR communications seem to be used to create obfuscation in stakeholders' minds.

\subsection{Corporate communication style}

A main risk in the implementation of CSR communication is the use of a cause-effect approach (Schoeneborn and Trittin, 2013). In other words, "CSR cannot be seen as a fixed script or tool that might be used by corporations to produce fixed effects such as legitimacy $[. .$.$] it represents a dynamic continuum of competing meanings. [...] the$ institutionalisation of CSR can be described as a multilevel process between several actors with an uncertain outcome" (Schultz and Wehmeir, 2010, p.13). This perspective could lead to considerations of two-way communication being as hazardous as unidirectional CSR communication if the main aim is to persuade stakeholders of the 'sustainability virtue' of the company. 
The 'only apparent option' therefore seems to be to adopt a low-profile approach to CSR communication (Morsing et al., 2008; van de Ven, 2008). We argue that some CSR communication activities are necessary, or at least cannot be avoided in specific industry contexts where being socially responsible is indispensable. However, to be effective, these communication activities must be focused on specific, verifiable facts (Berens and van Rekom, 2008; Cornelissen, 2008; Pomering and Johnson, 2009).

In deliberate greenwashing practices, companies use a selective disclosure mechanism to reveal disproportionally positive information and create an impression of sustainable performance (Marquis and Toffel, 2012). The selective disclosure of CSR information is often related to the exclusive use of company-controlled communications (mostly in the form of sustainability reports or mass-media advertisements). In other words, "there is likely to be a trade-off between the controllability and credibility of CSR communication; the less controllable the communicator is, the more credible it is, and vice versa" (Du et al., 2010, p.13). The result is that stakeholders perceive extrinsic (opportunistic) motives as predominant in companies' social initiatives (Parguel et al., 2011). On the other hand, the use of non-corporate sources in CSR communication, such as a third-party endorsement and/or independent information about company's sustainability (Swaen and Vanhamme, 2003; Parguel et al., 2011), may help to minimise stakeholder scepticism, increasing credibility of messages. The same positive effect on CSR communication credibility may be also reached, stimulating consumer word-ofmouth on social media (Du et al., 2010; Fieseler et al., 2010).

To illustrate concepts and characteristics of CSR communication and greenwashing, main features are presented in Table 1. This table describes the main dimensions of CSR communication (adapted from Morsing and Schultz, 2006) and presents several factors related to the appearance that a company is engaging in greenwashing practices, which arise from a failure to avoid pitfalls in CSR communication.

The identification of critical aspects of communication for each CSR dimension can be considered a starting point for determining gaps in sustainability communication and, therefore, may help to understand how organisations can draw together different CSR initiatives and avoid being accused of greenwashing.

On these grounds, the following research questions arise:

$R Q 1$. How CSR communications are likely to be influenced by the greenwashing effect?

$R Q 2$. What role does an awareness of the greenwashing risk play in avoiding communication shortcomings?

To answer to these questions from a practical perspective (in terms of pattern matching with theoretical propositions), we compared two energy companies, one from the Netherlands and one from Italy, and reviewed the parallelisms and discrepancies in their CSR communication and in how they avoided the greenwashing trap. The choice to analyse companies operating in two different countries is, actually, relevant also to compare both similarities/differences in CSR communication activities and the awareness of the greenwashing risk for companies with different cultural, legal and social backgrounds. Previous studies showed that that CSR is affected by national culture (Ho et al., 2012): for example, Nordic populations are traditionally more focused on environmental concerns than southern European ones (Halme and Huse, 1997). Some of these variables may influence what managers think about greenwashing risk and their CSR communications strategies (Maignan and Ralston, 2002). 
Table 1 Dimensions of CSR communication and root causes of greenwashing

\begin{tabular}{|c|c|}
\hline Dimensions of CSR communication & Greenwashing causes (pitfalls in CSR communication) \\
\hline \multirow{4}{*}{$\begin{array}{l}\text { Communication ideal } \\
\text { The idea of CSR that } \\
\text { the company wants to pursue }\end{array}$} & Unidirectional communication or superficially employed \\
\hline & $\begin{array}{l}\text { two-way communication (Crane and Livesey, 2003; Schultz } \\
\text { and Wehmeier, 2010; Schoeneborn and Trittin, 2013), often } \\
\text { caused by few points of contact and activities of } \\
\text { collaboration between company and stakeholders (Peloza } \\
\text { and Falkenberg, 2009) }\end{array}$ \\
\hline & $\begin{array}{l}\text { No/low correspondence between CSR communication } \\
\text { programs and stakeholder expectations (Brown and Dacin, } \\
\text { 1997; Sen and Bhattacharya, 2001; Swaen and Vanhamme, } \\
\text { 2003; Signitzer and Prexl, 2008; Dobers and Springett, } \\
\text { 2010) and/or corporate identity (Balmer et al., 2007; van de } \\
\text { Ven, 2008) }\end{array}$ \\
\hline & $\begin{array}{l}\text { Short-term commitment to problem solving (Waddock, } \\
\text { 2001; Pomering and Johnson, 2009) }\end{array}$ \\
\hline \multirow{4}{*}{$\begin{array}{l}\text { Identification of CSR structure } \\
\text { Definition of CSR decision- } \\
\text { making processes and flows }\end{array}$} & Determined by top management and not fully \\
\hline & $\begin{array}{l}\text { communicated inside the company or to stakeholders (Basu } \\
\text { and Palazzo, 2008; Ligeti and Oravecz, 2009) }\end{array}$ \\
\hline & $\begin{array}{l}\text { Ineffectiveness of intra-firm communication, causing } \\
\text { overstatement of sustainability aspects of a product/service } \\
\text { from PR/marketing departments (Delmas and Burbano, } \\
2011 \text { ) }\end{array}$ \\
\hline & $\begin{array}{l}\text { Inability to engage in dialogue with multiple stakeholder } \\
\text { groups (Weaver et al., 1999; Signitzer and Prexl, 2008) }\end{array}$ \\
\hline \multirow{4}{*}{$\begin{array}{l}\text { Strategic communication task } \\
\text { The rationale and objectives of CSR } \\
\text { communication strategy }\end{array}$} & Dissimulation of the nature of the problem (Brown and \\
\hline & \\
\hline & Unclear communication strategy (Dawkins, 2005) \\
\hline & $\begin{array}{l}\text { Profit-motivation as the prime reason to engage in CSR } \\
\text { (Becker-Olsen et al., 2006; Signitzer and Prexl, 2008) }\end{array}$ \\
\hline \multirow{4}{*}{$\begin{array}{l}\text { Corporate communication style } \\
\text { The main argument and style of CSR } \\
\text { communication initiatives }\end{array}$} & Generic description of CSR initiatives without specific \\
\hline & $\begin{array}{l}\text { accompanying facts/data (Berens an } \\
\text { Pomering and Johnson, 2009) }\end{array}$ \\
\hline & $\begin{array}{l}\text { Appealing messages not always based on reality } \\
\text { (Cornelissen, 2008) }\end{array}$ \\
\hline & $\begin{array}{l}\text { Lack of third-party endorsement or positive WOM (Du } \\
\text { et al., 2010; Fieseler et al., 2010; Parguel et al., 2011) }\end{array}$ \\
\hline
\end{tabular}

\section{Research design and methodology}

An analysis of two case studies is presented. There are specific industry reasons for the choice of these two companies (Enel and Eneco) ${ }^{1}$. We selected these two energy companies since several research point out that environmentally sensitive industries are considerably more devoted to environmental information disclosure (Kuo et al., 2012). Among different industrial sectors, energy companies in particular experience increasing pressure from specific stakeholders to offer sustainable products in the form of green energy. Despite the relative ease with which energy companies have adopted CSR and 
sustainability in their marketing communications (Ramus and Montiel, 2005), it is interesting to understand their perceptions of the greenwashing risk and how this affects their communication strategies.

The two companies we have selected for the development of explanatory case studies (Yin, 1994) will constitute a significant, critical test for our research questions and provide valuable information about CSR communication and greenwashing.

Compared with other research strategies, the use of qualitative interviews and a case study methodology allows us to gain a more in-depth understanding of the situation as well as to relate our findings to other contexts (Eisenhardt, 1989; Eisenhardt and Graebner, 2007). Thus, the study follows a qualitative approach (Ghauri and Gronhaug, 2002) and uses multiple sources of evidence to ensure construct validity (Yin, 1994).

Primary evidence was thus obtained from semi-structured interviews with key management informants from Enel and Eneco, and we also used secondary evidence from documents and material (the website, annual reports, press releases, TV commercials, print ads and social media) made available by these companies to backup the results gained analysing the primary data. In preparation for the interviews, a semistructured interview guide was drawn up that contained questions under seven sections. Our aim was to allow respondents a great deal of freedom to express their perceptions about their company's CSR communication in a language similar to the language they use for their daily work tasks (Bewley, 2002). We identified those managers with most responsibility for CSR communication. In one case, this was the CCO (corporate communication officer) and in the other it was the brand manager. After negotiating the issues to be discussed in the interviews, the final interview guide was translated into Italian and Dutch and the interviews were conducted in the native languages of the two managers. The interviews were transcribed in Italian and Dutch and then translated into English. To illustrate concepts and characteristics of the qualitative interviews on CSR communication and greenwashing, the main requests made during interviews with key managers are presented in Appendix I.

The interviews were both conducted in a face-to-face format. The main topics of the interview were sent to each interviewee by email prior to the appointment, which was made by telephone. Thus, participants had ample time to prepare for the interviews (Fontana and Frey, 1994). The questions asked during the interviews allowed the managers to provide answers in their own words about how CSR formed part of the company's communication strategy. The data were analysed in line with Lincoln and Guba (1985) and Patton (2002), and this involved aggregating the answers into the four dimensions of CSR communication, previously identified in the 'conceptual background' section.

\section{Analysis and discussion}

In this section we analyse the findings using a cross-case comparison based on pattern matching with the previously indicated research problems. Despite the limitations of the chosen method (Flyvbjerg, 2006), the comparison of the two cases is useful in addressing the research questions identified here. The analysis of the case studies is therefore carried out by building an explanation of the cases according to theoretical propositions. The comparisons between the predicted and the actual pattern do not have any quantitative 
criteria, and possible bias is due to the fact that it was necessary for researchers to use their discretion when interpreting the interviews (Trochim, 1989).

\subsection{Communication ideal (CSR)}

According to the Enel Manager, CSR plays an important role in Enel's corporate strategy. The definition of CSR that this manager provided ("the company's ability to balance economic, social and environmental dimensions in a virtuous circle") is in line with the current theoretical conceptualisations and definitions of the concept (Dahlsrud, 2008). Enel's CSR communication ideal seems to have two dimensions:

- a growth in dialogue and collaboration with stakeholders

- a greater integration of CSR (and sustainability communication) in Enel industrial plans.

According to the Eneco brand manager, stakeholders are struggling to understand the image of energy companies, largely because Eneco's main competitors portray themselves as "having the largest wind energy park in sea", or 'being the greenest', so that Eneco's message about sustainability appears to be just one message amongst many. Hence, Eneco's challenge in its communication is to position itself in a distinctive way that allows the company to continue to be perceived in terms of sustainability. Thus, both companies' CSR communication ideals seem to aim at avoiding the divergence of content that often takes organisations to fail to convey the actual information wanted or needed to pursue a stakeholder engagement strategy, and may instead contain prolix data available within the business. The interviewed managers said that their companies are fully engaged in long-term commitment in problem solving of social and environmental problems. With the managers being knowledgeable about the greenwashing debate, indeed, it is difficult to determine whether they, intentionally or not, alter their responses accordingly.

\subsection{Identification of CSR structure}

In both companies, the interviewees reported that corporate CSR decisions involve different organisational departments within the company and take into account the concerns of stakeholders. A similarity between the two companies can be found in the role played by employees: the basis of the relationship with all employees/departments is established on shared core values in terms of sustainability. In general, other research has found that employees are not consistently involved in CSR decision-making processes and flows, and they frequently receive one-way messages about CSR decisions made by the CEO and top managers (Ligeti and Oravecz, 2009). This means that companies fail to utilise the full potential of employees as active CSR ambassadors. Enel and Eneco do not appear to follow this trend. Employees are considered to be critically significant (Cramer et al., 2004), both because other stakeholders see them as convincing information sources, and because they constitute a useful way in which the company can gather CSR data for reporting.

Moreover, Enel clearly states that all stakeholders play a crucial role in the process of dialogue, proposal and implementation of CSR actions. To achieve this, the company aims to engage all operating units in all relevant projects. To foster collaboration with 
particular stakeholders (environmentalists, consumers, SMEs and local authorities), a great deal of attention is paid to communication. This involves organising events and meetings to disseminate company activities and distributing work tables, holding both closed and public workshops, and facilitating one-to-one events.

In comparison with the other energy companies in the Netherlands, Eneco has fewer coal factories, which makes it easier to engage different stakeholders:

\begin{abstract}
"We believe in non-central production of energy, together with our stakeholders. This means that everybody has solar panels in their garden. [...] What we are selling now (energy produced by oil, coal or gas) will be gone within a few decades, so we had to find something else. Not only because we want to be friendly for the world, but to have a business in the long term".
\end{abstract}

Perhaps not surprisingly, the two informants seem to be the strongest advocates of stakeholder engagement in CSR communication. Some doubts remain in relation to the way stakeholder engagement is perceived: it seems still linked to a 'multiplication' of means to disseminate company's view rather than to a shift towards a collaborative decision-making for CSR initiatives. In other terms, they seem to remain at the lower rungs of the stakeholder engagement ladder (Friedman and Miles, 2006), namely 'informing' and 'explaining', which are pushed by the aim of 'educating stakeholders' rather than assigning some decision-making power to stakeholders over specific projects.

\title{
4.3 Strategic communication task
}

The managers we spoke with said that the pressure exerted by various stakeholders, including environmental groups and consumer associations, is considered to be the main rationale for including CSR issues in communications and for avoiding the appearance of greenwashing. Moreover, this kind of voluntary disclosure gives to pressured companies an opportunity for expressing their side of the story in the environmental debate themselves, thereby protecting their own immaterial asset that becomes a strong base for stakeholder engagement. As part of Enel's strategy of fostering the virtuous behaviour of its customers to save energy and increase the use of renewable energy, the company is paying increasing attention to eco-friendly sources of energy for electric cars. The main risk for Enel in its communication strategy for CSR is represented by the company's support for nuclear energy. It should be noted, however, that Enel is involved in several initiatives for promoting dialogue with various stakeholders to disseminate knowledge on nuclear power and its ability to provide zero $\mathrm{CO}_{2}$ emissions.

The use of social media (for example, the YouTube channel 'enelvideo' and the 'Enel sharing' Facebook page) in external communication aims to stimulate participation in an innovative way. Enel thus considers it necessary to increase its points of contact and collaboration with customers and NGOs (Peloza and Falkenberg, 2009). Enel may have realised that the previous strategy that aimed to enhance interaction with stakeholders was more symbolic than factual, i.e., it was a stakeholder response strategy and its sole purpose was to convince constituencies of the company's attractiveness (Morsing and Schultz, 2006). It is interesting to note that Enel's presence on social media sites now constitutes an attempt to strengthen the company's two-way dialogue with consumers and to actively engage in micro-dialogues. This can provide a feedback mechanism for the organisation, giving valuable insights into consumer preferences and stakeholder concerns (Fieseler et al., 2010), enabling the sensemaking process. But on the other side, 
in a more transparent era with active social media monitoring, marketing communications pose serious risks to corporate reputation, due to increasing opportunities of negative word-of-mouth, such as 'tweetjacking' (Lyon and Montgomery, 2013). The case in point was the Enel's 2013 corporate campaign 'I Guerrieri' ('The Warriors'), which invited users to tell their stories of 'everyday heroes', especially for social and other charitable causes. Almost immediately, the hashtag \#guerrieri was 'hijacked' and used by environmental activists to strengthen their objections to Enel's energy policies, judged negative in terms of environmental impact.

The brand manager of Eneco asserted that CSR communication is relatively easy for Eneco to plan and implement because the company sells green energy and has sustainable business principles. Profit is not cited as a primary reason for Eneco to engage in CSR communication ("[...] we do not reveal that we are also in the game to make money"). Eneco's communication strategy has moved from a philanthropic focus ("Prior to 2007 we did do some charity work like painting a house for disabled people") to a value-chain or strategic approach ("We are still doing charity work, but now we have educational programs in schools on sustainable energy"). The company also sponsors environmentally friendly and sporting activities such as Eneco Tour, the main bicycle race in Benelux.

In both cases, engaging different stakeholder groups is the main strategic communication task. Indeed, the ideal aim of involving stakeholders in a concurrent dialogue is far from being achieved. Despite some positive results in specific areas (e.g., 'community relations' in the Enel case), effective two-way communication processes seem not to be the norm. The preferred way of engaging with stakeholders remains a one-way approach and, as we have seen above, a lack of dialogue increases the risk that a company will be accused of engaging in greenwashing practices.

\subsection{Corporate communication style}

Enel has often (directly or indirectly) used the issue of sustainability within its communication campaigns with contrasting results. In the past, Enel was criticised for using the word 'environment' to advertise its corporate bonds and, more generally, for using the notion of sustainability to suggest a 'green association' without presenting specific facts on the environmental actions taken by the company. Enel seems to be aware of this risk:

"Enel's CSR communication is always oriented to reflect an authentic
commitment, and we are aware that we could create a boomerang effect by
utilising an overpromising strategy on sustainability".

Recently, the references to sustainability in TV advertising seem to be used to create the background, or 'the story' in which the company can engage its consumers (e.g., a TV campaign entitled Energia Tutto Compreso, which aimed to promote a standard fee for energy according to three levels of consumption). More explicit messages are present in the 2011 corporate communications campaign entitled 'Il Viaggio' ('The Journey'), which focused on the contribution made by Enel to Italy and to the Italian community through the electrification of energy. This shows that the Italian company is aware that green brands with high involvement engage stakeholders in elaborate information processing and inference making, causing publics to infer more qualities and behaviour about themselves than from their consumption experience. 
According to the brand manager, all Eneco's marketing communications have a sustainability aspect ("Of course, we have a campaign about green energy, but that is used to attract more customers and is not meant to be societally involved"). A specific feature of Eneco's communications is the use of humourous situations (a case in point is the 2009 campaign named "From the wind, we cannot live"), but there is a strong sense that communications "always need to be in line with our business strategy". Despite this, a lack of consistency between CSR communication and business plans seems to be the most critical risk for Eneco. Other risks are identified as its 'self-referential nature', an inability to meet the differing needs of stakeholders, and the evaluation of the results of its communications.

\subsection{Influence and awareness of greenwashing risk and CSR communication shortcomings}

Answering to our first research question, we found that in both cases, CSR communications seem to be clearly influenced by an attempt to avoid the creation of a greenwashing effect, above all in terms of overpromising. Conversely, less attention is made to make the CSR communication included in a two-way discourse with stakeholders, in which the sustainable development is an overall process or 'story' that concerns both company's and consumer's choices.

The evaluation of CSR activities does not strongly affect communication at either company. Indeed, Enel provides a sustainability report that lists more than 450 KPIs on CSR, and has therefore chosen to adopt an approach focused on transparency, because it feels its record cannot be matched by its main competitors. At the same time, Eneco maintains that it suffers from sceptical stakeholder responses, mainly because of the negative halo effect of the energy industry in general ("the sector as a whole is greenwashing its image"). In both cases, the risk of appearing self-serving remains still high if precise data and facts are 'confined' exclusively in sustainability reports and absent in external communications. This hazard can be avoided with CSR narratives easy to comprehend, by using simple words, and fewer technical terms. CSR disclosure that is more concise and syntactically simple - while circumventing obfuscation - can therefore be taken to indicate that the firm's performance in terms of CSR was good.

Our second research question aims to understand how an awareness of the greenwashing risk can help to avoid pitfalls in the implementation of CSR communications in the two cases.

In both cases, the use of different means of communication to stimulate dialogue and the focus of CSR communication strategy on sustainable initiatives related to core business seem to be the main response to avoid risk of greenwashing in communications. Actually, the role of stakeholder engagement cannot always be seen as "corporate responsibility in action" but it risks to be perceived as another way of 'corporate spin'.

As for communication style, Enel is pursuing a type of communication that uses strong 'evocative' elements combined with rational and logical arguments to show a concrete commitment to sustainability. This position is partly in contrast to research that suggests that "[...] organisations typically do not use a rational message style when they communicate about their CSR because standards for performance in such areas are not obvious and transparent" (Cornelissen, 2008, p.105). Eneco, on the other hand, uses a different communication approach, probably more suited to the cultural habits of its public. Sustainability is always the main topic of messages, but these messages 
are communicated in different styles depending on the needs of individual projects/initiatives. In several commercials, the style is outspoken and friendly; humour is a way to ensure the conveyed message is memorable and to avoid 'overpromising'. Conversely, the use of typical marketing communication techniques (e.g., advertising, sponsorship) often adds a commercial dimension to the communication strategy, which could easily result in increased consumer scepticism. It is likely that the two different approaches of Enel and Eneco are related to the different cultural habits and social pressures faced by these companies (Ringov and Zollo, 2007; Ho et al., 2012). This could confirm the fact that several relevant determinants of CSR can be national-level factors such as laws, NGO concentration, societal culture, etc. (Campbell, 2007; Chih et al., 2010). Actually, Enel is constantly seen by environmentalists 'to defend' its core position in the production of conventional energy (due to its former monopoly in Italy), while Eneco is considered to be at the forefront of eco-sustainable solutions. Enel therefore needs to invest more in building trust relationships with its stakeholders, while Eneco has consistently emphasised its difference from its competitors.

\section{Implications, limitations and future research}

This paper makes several contributions to the existing literature on strategic CSR communication. First, it provides a theoretical contribution to the study of CSR communication by identifying several pitfalls that can lead CSR communications to create a misleading impression of corporate performance and therefore leave companies open to accusations of greenwashing. An examination of the relevant literature reveals that the link between greenwashing and pitfalls in CSR communication has never been fully substantiated. Thus, this paper lays a foundation for further development of both theory and practice in the area. Deliberate greenwashing practices seem to be only a part of the symbolic discourse of overall CSR activities (Bowen and Aragon-Correa, 2014). The identification of different drawbacks in CSR communication and the proposed method of analysis, based on communication dimensions and stakeholder engagement, may guide further studies to consider different facets of the identity-washing phenomenon also in other industries (e.g., consumer goods).

Second, this paper offers information about the behaviour of companies that are aware of the risk of appearing to be involved in greenwashing. Indeed, an understanding of the greenwashing risk influences the overall management of CSR communication and may lead companies to embrace a strategic CSR approach. Conversely, a reactive approach to CSR communication still seems to be the norm; the necessity of avoiding greenwashing accusations would instead make companies play a proactive role in CSR communication, i.e., enhancing the internal organisational capacity to act. In terms of communication, stakeholder engagement may be reached only with symmetrical two-way communication in which the company is 'influential' in the creation of CSR initiatives and accepts not only to dedicate time to building trust but also to recognise stakeholders' role in CSR decision-making. This means that stakeholder engagement cannot be used per se (as a communication technique) to seek positive stakeholder attributions to their CSR activities. 
From a practical standpoint, it seems that avoiding greenwashing accusations in terms of corporate communication could be summarised in two main recommendations:

- 'Telling the truth', i.e., express company's environmental commitment with information richness and fact-based language. Managers should avoid selective disclosure and decoupling strategies in CSR communications, conveying a balanced view of actions and initiatives. In this direction, the use of certifications, straightforward language and messages with specific data may reduce stakeholder scepticism.

- 'Telling the story', explaining both the firm and the consumer's role in the process of environmental sustainability. 'Telling the story' does not mean the CSR activities should be portrayed as the organisation's sole purpose but it involves presenting the full impact of a product/service and what each actor can do to contribute to the overall process.

However, there are several caveats that should be considered in relation to our research findings and implications. Limitations of our study concern both specific circumstances and types of firms - only two energy companies were used as example - and a literature-based approach in defining greenwashing communication drivers. Several avenues for further research therefore exist, first of all, there is the need to expand the observation to companies in other industries. An additional step will be to deepen these propositions with perceptual measurements derived from a questionnaire-based survey or specific experimental design to test them from the point of view of consumers. The study of greenwashing could gain more interest if the analysis could be extended to the perception that consumers have about the communication model of companies under investigation.

From a managerial standpoint, an important priority would be to explore the design and implementation of strategies that aim to avoid greenwashing, i.e., "what to say - and then how to say it - about an organisation's CSR programs and achievements, without appearing self-serving or risking stakeholder cynicism" (Lindgreen and Swaen, 2010, p.2). This would further contribute to the understanding developed here of how companies can successfully align their communication practices with an effective CSR strategy.

\section{References}

Aras, G. and Crowther, D. (2009) 'Corporate sustainability reporting: a study in disingenuity?', Journal of Business Ethics, Vol. 87, No. 1, pp.279-288.

Athanasiou, T. (1996) 'The age of greenwashing', Capitalism, Nature, Socialism, Vol. 7, No. 1, pp.1-36.

Balmer, J., Fukukawa, T.K., Gray, J.M.T. and Lehti, E.R. (2007) 'The nature and management of ethical corporate identity: a commentary on corporate identity, corporate social responsibility and ethics', Journal of Business Ethics, Vol. 76, No. 1, pp.7-15.

Basu, K. and Palazzo, G. (2008) 'Corporate social responsibility: a process model of sensemaking', Academy of Management Review, Vol. 33, No. 1, pp.122-136.

Bazillier, R. and Vauday, J. (2010) 'CSR and Greenwashing', in Crifo, P. and Ponssard, J-P. (Eds.): Corporate Social Responsibility: from Compliance to Opportunity?, Ecole Polytechnique, Paris. 
Bebbington, I.J., Brown, F.B. and Thomson, I. (2007) 'Theorizing engagement: the potential of a critical dialogic approach', Accounting, Auditing and Accountability Journal, Vol. 20, No. 3 , pp.356-381.

Becker-Olsen, K.L., Cudmore, B.A. and Hill, R.P. (2006) 'The impact of perceived corporate social responsibility on consumer behavior', Journal of Business Research, Vol. 59, No. 1, pp.46-53.

Berens, G.A.J.M. and van Rekom, J. (2008) 'How specific should corporate communication be? The role of advertising language in establishing a corporate reputation for CSR', in Melewar, T.C. (Ed.): Facets of Corporate Identity, Communication and Reputation, Routledge, London, pp.96-119.

Bewley, T.F. (2002) 'Interviews as a valid empirical tool in economics', Journal of Socioeconomics, Vol. 31, No. 4, pp.343-353.

Bowen, F. and Aragon-Correa, J.A. (2014) 'Greenwashing in corporate environmentalism research and practice: the importance of what we say and do', Organization and Environment, Vol. 27, No. 2, pp.107-112.

Brown, T.J. and Dacin, P.A. (1997) 'The company and the product: corporate associations and consumer product responses', Journal of Marketing, Vol. 61, No. 1, pp.68-84.

Campbell, J.L. (2007) 'Why would corporations behave in socially responsible ways? An institutional theory of corporate social responsibility', The Academy of Management Review, Vol. 32, No. 3, pp. 946-967.

Chih, H-l., Chih, H-h. and Chen, T-y. (2010) 'On the determinants of corporate social responsibility: international evidence on the financial industry', Journal of Business Ethics, Vol. 93, No. 1, pp.115-135.

Cone Communications (2012) Green Gap Trend Tracker, Retrieved from http://www.conecomm. com (Accessed 24 January, 2014).

Cornelissen, J. (2008) Corporate Communication, A guide to theory and practice, Sage Publishing, London.

Cramer, J., Jonker, J. and van der Heijden, A. (2004) 'Making sense of corporate social responsibility', Journal of Business Ethics, Vol. 55, No. 2, pp.215-222.

Crane, A. and Livesey, S. (2003) 'Are you talking to me? Stakeholder communication and the risks and rewards of dialogue', in Andriof, J., Waddock, S., Husted, B. and Sutherland Rahman, S. (Eds.): Unfolding Stakeholder Thinking: Relationships, Communication, Reporting and Performance, Greenleaf Books, Sheffield, pp.39-52.

Dahlsrud, A. (2008) 'How corporate social responsibility is defined: an analysis of 37 definitions', Corporate Social Responsibility and Environmental Management, Vol. 15, No. 1, pp.1-13.

Dawkins, J. (2005) 'Corporate responsibility: the communication challenge', Journal of Communication Management, Vol. 9, No. 2, pp.108-119.

Delmas, M.A. and Burbano, V.C. (2011) 'The drivers of greenwashing', California Management Review, Vol. 54, No. 1, pp.64-87.

Dobers, P. and Springett, D. (2010) 'Corporate social responsibility: discourse, narratives and communication', Corporate Social Responsibility and Environmental Management, Vol. 17, No. 2, pp.63-69.

Du, S., Bhattacharya, C.B. and Sen, S. (2010) 'Maximizing business returns to Corporate Social Responsibility (CSR): the role of CSR communication', International Journal of Management Reviews, Vol. 12, No.1, pp.8-19.

Eisenhardt, K.M. (1989), 'Building theories from case study research', Academy of Management Review, Vol. 14, No. 4, pp.532-550.

Eisenhardt, K.M. and Graebner, M.E. (2007) 'Theory building from cases: opportunities and challenges', Academy of Management Journal, Vol. 50, No. 1, pp.25-32. 
Elving, W.J.L. and van Vuuren, H.A.M. (2011) 'Beyond identity washing: corporate social responsibility in an age of skepticism', Akademija MM (Slovenian Journal of Marketing), Vol. 17, pp.40-49.

Eurobarometer (2009) Europeans' Attitudes Towards the Issue of Sustainable Consumption and Production, Flash Eurobarometer 256.

Fieseler, C., Fleck, M. and Meckel, M. (2010) 'Corporate Social Responsibility in the Blogosphere', Journal of Business Ethics, Vol. 91, No. 4, pp.599-614.

Flyvbjerg, B. (2006) 'Five misunderstandings about case study research', Qualitative Inquiry, Vol. 12, No. 2, pp.219-245.

Fontana, A. and Frey, J.H. (1994) 'Interviewing: the art of science', in Denzin, N.K. and Lincoln, Y.S. (Eds.): Handbook of Qualitative Research, Sage Publishing, Thousand Oaks, CA, pp.361-376.

Freeman, R.E. and McVea, J. (2001) 'A stakeholder approach to strategic management', in Hitt, M.A., Freeman, R.E. and Harrison, J.S. (Eds.): Handbook of Strategic Management, Blackwell Publishers, Oxford, UK, pp.189-207.

Friedman, A.L. and Miles, S. (2006) Stakeholders: Theory and Practice, Oxford University Press, Oxford.

Ghauri, P.N. and Gronhaug, K. (2002) Research Methods in Business Studies: A Practical Guide, 2nd ed., Financial Times Prentice-Hall, London.

Gioia, D.A., Thomas, J.B., Clark, S.M. and Chittipeddi, K. (1994) 'Symbolism and strategic change in academia: the dynamics of sensemaking and influence', Organization Science, Vol. 5, No. 3, pp.363-383.

Greenwood, M. (2007) 'Stakeholder engagement: beyond the myth of corporate responsibility', Journal of Business Ethics, Vol. 74, No. 4, pp.315-327.

Grunig, J.E. and Hunt, T. (1984) Managing Public Relations, Holt, Rinehart and Winston, Fort Worth, TX.

Halme, M. and Huse, M. (1997) 'The influence of corporate governance, industry and country factors on environmental reporting', Scandinavian Journal of Management, Vol. 13, No. 2, pp.137-157.

Harris Interactive (2012) Green Still Follows Green: The Environment Retains Influence on Spending, retrieved from http://www.harrisinteractive.com/NewsRoom/HarrisPolls/tabid/ 447/ctl/ReadCustom\%20Default/mid/1508/ArticleId/1070/Default.aspx (Accessed 24 July, 2014)

Ho, F.N., Wang, H.M.D. and Vitell, S.J. (2012) 'A global analysis of corporate social performance: The effects of cultural and geographic environments', Journal of Business Ethics, Vol. 107, No. 4, pp.423-433.

Ilia, L., Zyglidopoulos, S.C., Romenti, S., Canovas, B.R. and Brena, A.D. (2013) 'Communicating corporate social responsibility to a cynical public', MIT Sloan Management Review, Vol. 54, No. 3, pp.16-18.

Jahdi, K. and Acikdilli, G. (2009) 'Marketing communications and corporate social responsibility: Marriage of convenience or shotgun wedding?', Journal of Business Ethics, Vol. 88, No. 1, pp.103-113.

James, N. and Phillips, R. (2010) 'Stakeholder engagement, discourse ethics and strategic management', International Journal of Management Reviews, Vol. 12, No. 1, pp.39-49.

Kuo, L., Yeh, C-C. and Yu, H-C. (2012) 'Disclosure of corporate social responsibility and environmental management: evidence from China', Corporate Social Responsibility and Environmental Management, Vol. 19, No. 5, pp.273-287.

Laufer, W.S. (2003) 'Social accountability and corporate greenwashing', Journal of Business Ethics, Vol. 43, No. 3, pp.253-261. 
Ligeti, G. and Oravecz, A. (2009) 'CSR communication of corporate enterprises in Hungary', Journal of Business Ethics, Vol. 84, No. 2, pp.137-149.

Lincoln, Y.S. and Guba, E.G. (1985) Naturalistic Inquiry, Sage Publishing, Beverly Hills, CA.

Lindgreen, A. and Swaen, V. (2010) 'Corporate social responsibility', International Journal of Management Reviews, Vol. 12, No. 1, pp.1-7.

Lyon, T.P. and Maxwell, J.W. (2011) 'Greenwash: environmental disclosure under threat of audit', Journal of Economics and Management Strategy, Vol. 20, No. 1, pp.3-41.

Lyon, T.P. and Montgomery, A.W. (2013) 'Tweetjacked: The impact of social media on corporate greenwash', Journal of Business Ethics, Vol. 118, No. 4, pp.747-757.

Maignan, I. and Ralston, D.A. (2002) 'Corporate social responsibility in Europe and the US: insights from businesses' self-presentations', Journal of International Business Studies, Vol. 33, No. 3, pp.497-514.

Marquis, C. and Toffel, M.W. (2012) When Do Firms Greenwash? Corporate Visibility, Civil Society Scrutiny, and Environmental Disclosure, Harvard Business School Organizational Behavior Unit Working Paper, No. 11-115 (4 August, 2012), available at http://dx.doi.org/10.2139/ssrn.1836472 (Accessed 24 October, 2013).

Miles, M.P., Munilla, L.S. and Darroch, J. (2006) 'The role of strategic conversations with stakeholders in the formation of corporate social responsibility strategy', Journal Business Ethics, Vol. 69, No. 2, pp.195-205.

Morsing, M. and Schultz, M. (2006) 'Corporate social responsibility communication: stakeholder information, response and involvement strategies', Business Ethics: a European Review, Vol. 15, No. 4, pp.323-338.

Morsing, M., Schultz, M. and Nielsen, K.U. (2008) 'The 'Catch 22' of communicating CSR: Findings from a Danish study', Journal of Marketing Communications, Vol. 14, No. 2, pp.97-111.

National Geographic/GlobeScan (2012) Greendex 2012: Consumer Choice and the Environment, Retrieved from http://environment.nationalgeographic.com (Accessed 24 January, 2014).

Parguel, B., Benoit-Moreau, F. and Larceneux, F. (2011) 'How sustainability ratings might deter 'greenwashing': a closer look at ethical corporate communication', Journal of Business Ethics, Vol. 102, No. 1, pp.15-28.

Patton, M.Q. (2002), Qualitative Research and Evaluation Methods, Sage Publishing, Thousand Oaks, CA.

Peloza, J. and Falkenberg, L. (2009) 'The role of collaboration in achieving corporate social responsibility objectives', California Management Review, Vol. 51, No. 3, pp.95-113.

Perrini, F. and Tencati, A. (2008) 'La responsabilità sociale d'impresa: strategia per l'impresa relazionale e innovazione per la sostenibilità', Sinergie Italian Journal of Management, Vol. 77, pp.23-43.

Pomering, A. and Johnson, L.W. (2009) 'Constructing a corporate social responsibility reputation using corporate image advertising', Australasian Marketing Journal, Vol. 17, No. 2, pp.106-114.

Ramus, C.A. and Montiel, I. (2005) 'When are corporate environmental policies a form of 'greenwashing'?', Business and Society, Vol. 44, No. 4, pp.377-417.

Ringov, D. and Zollo, M. (2007) 'The impact of national culture on corporate social performance', Corporate Governance, Vol. 7, No. 4, pp.476-485.

Schlegelmilch, B.B. and Pollach, I. (2005) 'The perils and opportunities of communicating corporate ethics', Journal of Marketing Management, Vol. 21, Nos. 3-4, pp.267-290.

Schmeltz, L. (2014) 'Introducing value-based framing as a strategy for communicating CSR', Social Responsibility Journal, Vol. 10, No. 1, pp.184-206. 
Schoeneborn, D. and Trittin, H. (2013) 'Transcending transmission: towards a constitutive perspective on CSR communication', Corporate Communication: An International Journal, Vol. 18, No. 2, pp.193-211.

Schultz, F. and Wehmeier, S. (2010) 'Institutionalization of corporate social responsibility within corporate communications. Combining institutional, sensemaking and communication perspectives', Corporate Communications: An International Journal, Vol. 15, No. 1, pp.9-29.

Sen, S. and Bhattacharya, C.B. (2001) 'Does doing good always lead to doing better? Consumer reactions to corporate social responsibility', Journal of Marketing Research, Vol. 38, No. 2, pp.225-243.

Siano, A., Vollero, A., Confetto, M.G. and Siglioccolo, M. (2013) 'Corporate communication management: a framework based on decision-making with reference to communication resources', Journal of Marketing Communications, Vol. 19, No. 2, pp.151-167.

Signitzer, B. and Prexl, A. (2008) 'Corporate sustainability communications: aspects of theory and professionalization', Journal of Public Relations Research, Vol. 20, No. 1, pp.1-19.

Swaen, V. and Vanhamme, J. (2003) 'See how 'good' we are: the dangers of using corporate social activities in communication campaigns', in Kahn, B.E. and Luce, M.F. (Eds.): Advances in Consumer Research, Vol. XXXI, Toronto, Canada, pp.302-303.

Thomson, I. and Bebbington, J. (2005) 'Social and environmental reporting in the UK: a pedagogic evaluation', Critical Perspectives on Accounting, Vol. 16, No. 5, pp.507-533.

Trochim, W. (1989) 'Outcome pattern matching and program theory', Evaluation and Program Planning, Vol. 12, No. 4, pp.355-366.

van de Ven, B. (2008) 'An ethical framework for the marketing of corporate social responsibility', Journal of Business Ethics, Vol. 82, No. 2, pp.339-352.

Veleva, V.R. (2010) 'Managing corporate citizenship: a new tool for companies', Corporate Social Responsibility and Environmental Management, Vol. 17, No. 1, pp.40-51.

Vollero, A. (2013) 'Il rischio di greenwashing nella comunicazione per la sostenibilità: implicazioni manageriali', Sinergie Italian Journal of Management, Vol. 92, pp.3-23.

Waddock, S.A. (2001) 'Integrity and mindfulness: foundations of corporate citizenship', in Andriof, J., Mclntosh, M. and Amhenst, N.Y. (Eds.): Perspectives on Corporate Citizenship, Greenleaf Publishing, Sheffield, pp.26-38.

Weaver, G.R., Trevino, L.K. and Cochran, P.L. (1999) 'Integrated and decoupled corporate social performance: management commitments, external pressures, and corporate ethics practices', Academy of Management Journal, Vol. 42, No. 5, pp.539-552.

Weick, K.E. (1995) Sensemaking in Organizations, Sage Publishing, Thousand Oaks, CA.

Yin, R. (1994) Case Study Research: Design and Methods, 2nd ed., Sage Publishing, Thousand Oaks, CA.

Ziek, P. (2009) 'Making sense of CSR communication', Corporate Social Responsibility and Environmental Management, Vol. 16, No. 3, pp.137-145.

Ziemann, A. (2011) 'Communication theory and sustainability discourse', in Godemann, J. and Michelsen, G. (Eds.): Sustainability Communication: Interdisciplinary Perspectives and Theoretical Foundation, Springer, Dordrecht, The Netherlands, pp.89-96.

\footnotetext{
Note

${ }^{1}$ Enel is Italy's largest power company, operating in 40 countries over four continents and has over 78,000 employees. In recent years Enel has received several international awards in the 'Corporate Responsibility' category (e.g., European Business Awards' Ruban d'Honneur) and has been included in the world's most important sustainability indexes. Eneco is one of the top three energy companies in the Netherlands and serves over two million business and domestic customers. Eneco is a sponsor of the Dutch branch of the World Nature Fund (WNF) and is the first Dutch partner of WWF Climate Savers Program.
} 
Appendix I Interview topic list

\begin{tabular}{l} 
Topics \\
\hline $\begin{array}{l}\text { Definitions of CSR and } \\
\text { stakeholder engageme }\end{array}$ \\
CSR and stakeholder \\
engagement projects
\end{tabular}

CSR and stakeholder engagement within the company

External CSR communication (in general)
Interview guide

1 What are your definitions of Corporate Social Responsibility and stakeholder engagement?

2 What do you think is part of CSR and what not?

3 What is the objective that your organisation want to pursue with CSR communication?

4 On what fields is the organisation active regarding CSR?

5 What was the occasion for your company to start with CSR?

6 How did you decide which CSR programs were suitable for your company (and not considered just made to pursue a greenwashing scope)?

7 Do your CSR activities and the stakeholder engagement approach have to fit with your core business or your products? Why/Why not?

8 Do your CSR activities fit with your stakeholders expectations? Is your CSR relevant for consumers?

9 How did you incorporate your CSR activities and the stakeholder engagement approach within the company? How do you establish this? On a systematic way?

10 Is there a department or sub department for CSR in the company?

a If not, how do you organise your CSR activities? Who is responsible?

b If yes, how many people are involved and under which department is this located?

c To what extent is the CEO or top management involved?

11 What is necessary to implement the CSR activities and the stakeholder engagement approach within the organisation?

12 Do you use societal issues in your corporate and/or marketing communications?

a If not, what is the reason for this (continue with Q16)

$\mathrm{b}$ If yes, what communication channels/media do you use to communicate about CSR and with what reason?

13 What was the reason to start with external communication about CSR?

14 What are your motives to communicate externally (communicate with stakeholders) about CSR?

15 Do you communicate about the goals of your CSR activities in the external communication? 
Appendix I Interview topic list (continued)

\begin{tabular}{|c|c|c|}
\hline Topics & Inte & rview guide \\
\hline \multirow{7}{*}{$\begin{array}{l}\text { External CSR communication } \\
\text { (in general) }\end{array}$} & 16 & What is your communication strategy? \\
\hline & & a Cognitive (sharing information) or emotional? \\
\hline & & $\begin{array}{l}\text { b What is the main reason to engage in CSR } \\
\text { communication? }\end{array}$ \\
\hline & 17 & $\begin{array}{l}\text { Do you communicate proactive or reactive (response) on } \\
\text { your CSR activities? }\end{array}$ \\
\hline & 18 & $\begin{array}{l}\text { Do you mention facts about your CSR activities } \\
\left.\text { (e.g., reduction of XXX tonnes of } \mathrm{CO}_{2}\right) \text { ? }\end{array}$ \\
\hline & 19 & $\begin{array}{l}\text { Do you think that your stakeholders care about your CSR } \\
\text { activities? }\end{array}$ \\
\hline & 20 & $\begin{array}{l}\text { Has there been negative press on your CSR activities in the } \\
\text { past? }\end{array}$ \\
\hline \multirow{7}{*}{$\begin{array}{l}\text { Do's and Don'ts } \\
\text { (awareness of greenwashing } \\
\text { risk) }\end{array}$} & 21 & $\begin{array}{l}\text { What do you do to communicate trustworthy about your } \\
\text { CSR? }\end{array}$ \\
\hline & 22 & Are you not afraid of window dressing/greenwashing? \\
\hline & 23 & $\begin{array}{l}\text { How can your organisation integrate CSR in its } \\
\text { marketing/communication activities? }\end{array}$ \\
\hline & 24 & $\begin{array}{l}\text { What are the conditions to be able to find suitable } \\
\text { communication on your CSR activities trying to avoid the } \\
\text { greenwashing trap? }\end{array}$ \\
\hline & 25 & $\begin{array}{l}\text { What do you think are the success factors with CSR } \\
\text { communication? Do you think there are examples of } \\
\text { successful CSR communication? }\end{array}$ \\
\hline & 26 & $\begin{array}{l}\text { What do you think are the factors that can make CSR } \\
\text { communication to a failure? }\end{array}$ \\
\hline & 27 & What are the risks of a failure in CSR communication? \\
\hline \multirow{4}{*}{$\begin{array}{l}\text { Evaluation of CSR } \\
\text { communication }\end{array}$} & 29 & Do you evaluate the external communication of your CSR? \\
\hline & & $\begin{array}{l}\text { a If yes, how? Did the outcomes of this evaluation lead to } \\
\text { adjustments in your CSR policies/activities? }\end{array}$ \\
\hline & & b If not, why not? \\
\hline & 30 & $\begin{array}{l}\text { Did you reach specific targets with your CSR activities } \\
\text { (e.g., development of corporate image and/or reputation; } \\
\text { purchase intention of consumers)? }\end{array}$ \\
\hline
\end{tabular}

